\title{
VIRTUE EDUCATION PROGRAMME E-TAP: INNOVATIVENESS AND THEMATIC FIT IN THE CONTEXT OF PRESCHOOL AND PRIMARY EDUCATION IN LATVIA
}

\author{
Manuel Joaquín Fernández González, Beāte Balandīna, \\ Linda Kovalıvska \\ University of Latvia, Latvia
}

\begin{abstract}
This study addresses the appropriateness ('fit') of the moral education programme e-TAP to the Latvian educational context from preschool till grade 3. Document analysis and a questionnaire were used for exploring two research questions: How do the topics of e-TAP fit the topics of the new competence-based curriculum Skola 2030? and what was the e-TAP fit the needs, expectations, and values of the educational context? The document base contained 20 Skola 2030 "Subject matter model programmes" (63 content-units in preschool and 174 topics in grades 1-3) and 64 e-TAP lesson plans (24 in preschool and 40 in grades 1-3). 138 teachers (78 form preschool and 60 from grades 1-3) piloted the e-TAP programme between February and April 2021 and filled 169 feedback questionnaires containing information about their interest in the programme, their motivations and satisfaction with the programme, and their suggestions for improving it. NVivo and MS Excel software were used for qualitative and quantitative data analysis. The results show the high thematic fit of e-TAP with Skola 2030: nearly half of the Skola 2030 topics had at least a thematic match with the e-TAP lesson plans, and $83 \%$ of e-TAP lesson plans match with at least one of the Skola 2030 topics. Almost all teachers agreed or rather agreed that the e-TAP programme fits to their needs, expectations, and values. The programme innovativeness, fit to teachers' needs and relation to Latvian traditions are discussed, and directions for programme development and future research are suggested.
\end{abstract}

Keywords: fit analysis, innovation, preschool education, primary education, Skola 2030, traditions, virtue education.

\section{Introduction}

This study presents the analysis of an innovative programme for moral education in preschool and primary school settings in Latvia. The programme appropriateness ('fit') to the Latvian sociocultural context and to 
the needs and expectations of the educational actors is explored. To situate the study, an introduction about the relations between "tradition" and "innovation" particularly in the field of moral education at school, may be useful.

Tradition is a pattern of notions and actions in a certain group of people that is handed down from generation to generation (Baldunčiks \& Pokrotniece, 1999). The word "tradition" originates from the Latin word "tradere" - to transmit; to hand over (Kūle, 2005). Anthropologists and sociologists consider the tradition to be a deliberate choice of past actions honoured for a long time. Tradition usually associates with something ancient, while the present times - with the current events, and the future with dreams, fantasies, and utopia. It is believed that the past is the basis for the current events (Kūle, 2005). The present world differs from the world of other ages: social interactions and conflicts, and constant cultural, economic and technological development, have transformed human life. Traditions are considered as one of the forming components of culture and an element of social expression (Alewov \& Utemuratova, 2021). As social groups may subjectively perceive and interpret their traditions differently, observing a tradition through a unique prism can be quite limiting. Traditions are not easily available for radical changes, but traditional aspects can be blended into innovations quite easily. Traditions and established knowledge can be very useful for future generations and promote innovation processes (Ferreiro et al., 2019).

Every innovation has a certain continuity with tradition, which therefore cannot be strictly ignored or rejected as such, lest social and political harm happens (Mitchell, 2013). Taking into consideration the changing modern world, values and cultural artifacts that were relevant in the past may have lost part of their significance. Traditions should be alive: moving with the times, linked to innovations, and somehow adapting to modern tendencies. Most of innovations occur in the field of technologies: they are science-based and use research, production, and patenting processes (Hong et al., 2012). Natural science, mathematical and technology research differ from research in social sciences and humanities, but, as recent research has emphasized, in both fields, innovation is based on previous knowledge (Katila, 2002).

Innovations in pedagogy can be considered as new products implemented into educational practice, such as new educational contents, curricula, methods, tools, etc. (Serdyukov, 2017). In Latvia, the most recent educational innovation is the new competency-based learning approach, which started from September 2020 in pre-school, $1^{\text {st }}, 4^{\text {th }}, 6^{\text {th }}, 10^{\text {th }}$ grades (Skola 2030, 2020). The most important element in implementing innovation in education is the teacher. In the teacher's profession traditions are 
highly valued, but also the adjustments innovations make in the education process. Teachers are experts who use traditions and both established and cutting-edge knowledge to inspire students to form an independent and well-developed personality, and to become valuable members of society, as stated in the Law of Education of Latvia (Latvijas Vēstnesis, 2020, p. 224).

One of the most important goals of education is moral upbringing, and currently in Latvia pupils' moral education is topical. The transfer of values and virtues through the education system was spotlighted in 2015 and later in 2016, when the "Guidelines for pupils' upbringing" were adopted (Latvijas Vēstnesis, 2016, p. 141). Through those guidelines, the learner is encouraged to become a good person - a virtuous, morally capable, and responsible personality in a society that is loyal to the State of Latvia and the Constitution of the Republic of Latvia. In the guidelines of students' education, it is stated that students are supposed to develop 12 main virtues at school (Latvijas Vēstnesis, 2016, p. 141). Virtues are stable, inner moral characteristics, e. g., justice, honesty, integrity, kindness (The Jubilee Centre, 2017). These moral habits or dispositions are guided by values, acquired through practice, and "produce specific moral emotions, inform motivation and guide conduct" (The Jubilee Centre, 2017). Practicing virtues (from Greek AбкÉv (askēin) - to exercise, train, also to embellish or refine a material) has always been an important part of European culture since the ancient Greek philosophy. Without virtues, a person has no moral strength to achieve the good (values) (Kiope, 2015). Virtues play a great role not only in a student's educational process but also later in life, as virtues give meaning to life and help maintain one's well-being (Lakota et al., 2016). As moral feelings arise and develop during childhood, an excellent way of strengthening virtues is to address them at early stages of education.

Teachers play an important role in forming students' understanding of virtues, because virtues develop by practice (Skola 2030, 2017) and youngsters spend a lot of time at school. A recent research report about the Latvian sociocultural context in the field of character education (Fernández González, 2019), in which more than 2250 respondents from different educational sectors were involved, argued that family-school collaboration is crucial for effective moral education. In addition, in-service teachers need methodological materials and guidelines in order to comply with Latvian legislation and current reforms regarding moral education (Pigozne et al., 2020). The virtue education programme e-TAP, which is analysed in this paper, was conceived as a response to this need. Originally developed in the United Kingdom by the Jubilee Centre for Character and Virtues of the University of Birmingham, it was adapted to 
the Latvian education system in late 2020. The aim of this programme is to support character and virtue education at school among pupils from 5 till 15 years old (for a description of the e-TAP programme, see Fernández González et al., 2021).

Before implementing an education program, it is necessary to verify its alignment with the needs of the organization and the community (CMFR, 2020, p. 1). According to Eldridge and colleagues (2016), "fit research" looks at the appropriateness of a programme to a concrete cultural or institutional context. Programmes with a good 'fit' have a higher chance of reaching the intended outcomes with the target audience (CMFR, 2020, p. 4). The use of feedback evaluation questionnaires in fit research is quite frequent (e. g., Bumbarger, 2020; CMFR, 2020). Recent research about programme fit addressed questions such: "Does the program align with the culture and values of the community, stakeholders, and target population?" (CMFR, 2020, p. 2). Similarly, in the USA, recent research suggests addressing questions about how well the program's theory matches the identified needs and whether the program fits the culture and beliefs of the target population (Bumbarger, 2020, p. 3).

The problems addressed by this research are the lack of any similar programme in this field in Latvia, the high expectations of the education sector regarding materials for moral education, and the significant differences regarding the moral education traditions and systems between Latvia and England, from where the original programme was adapted. Therefore, it was particularly important to provide solid scientific evidence regarding whether the e-TAP programme had an appropriate fit to the sociocultural context of the country and to the needs of teachers, which is the purpose of this research.

For addressing these challenges, the programme e-TAP was piloted from February till April 2021 by more than 250 teachers in 96 educational institutions in Latvia. The research presented in this paper focuses on preschool and primary school teachers' views about the appropriateness (fit) and innovativeness of the e-TAP programme to the Latvian education system. In addition, given the importance of the new competence-based curriculum Skola 2030 at all levels of education, special attention was given to the correspondence of the e-TAP programme topics to the Skola 2030 programme topics. Therefore, the research questions guiding the research question (RQ) were formulated as follows:

RQ-1. How do the topics of the virtue education programme e-TAP fit the topics of the competence-based curriculum Skola 2030?

RQ-2. How did preschool and basic education teachers perceive the fit of the virtue education programme e-TAP to the needs, expectations, and values of the educational context? 


\section{Method}

The exploration of the first research question (thematic fit between e-TAP and Skola 2030) was based on document analysis of two document sets: the documents of the Skola 2030 curriculum called "Subject matter model programmes" from preschool till grade 3 (20 documents, see Table 1), were compared with the lesson plans of the e-TAP programme $(N=118)$. The basic education programme of Skola 2030 is structured in seven thematic areas, which are broken down into different subject matters addressing different topics, between 4 and 7 for each grade. Overall, there are 174 topics from grade 1 to 3 . In preschool education, each thematic area is divided into "content units". Overall, there are 63 content units in preschool education. In its turn, the e-TAP curriculum contains 3-4 themes for each grade, from preschool (5 years) till grade 9 . Each theme had 2 or 3 lesson plans with topics related to the theme. Overall, there are a total of 64 lesson plans from preschool (5 years) till grade 3.

For comparing the two document sets, first the Skola 2030 content units and topics were explored, looking for keywords corresponding to the topics of the e-TAP lesson plans. An initial list of 43 possible matches with preschool and 130 matches withing grades 1 to 3 was established. Then, ten experts (three researchers, three university teaching staff and four master and doctoral students) made a detailed content analysis based on the initial matching list for creating an "Inventory of matches" completing the initial matches when necessary and also rejecting some of them. This inventory was finally analysed, using frequency analysis of matches.

For the analysis of the second research question (e-TAP fit to Latvian educational context), several tools and criteria were used. First, all the teachers who participated in the e-TAP piloting filled a feedback questionnaire after piloting each lesson plan (950 questionnaires were received) and each whole theme (360 questionnaires). The "theme questionnaire" contained, among other sections, a set of six questions in a 4-point Likert scale and an open question regarding teachers' views about the programme fit to the Latvian sociocultural context, educational institution culture and values, their own value system and pupils' needs and interests (see Table 3). 169 theme questionnaires were analysed in this research: 75 from preschool teachers and 94 from teachers working in grades 1-3.

In addition, teachers' interest in the programme, their participation and retention level, their motivations and satisfaction, and their suggestions for improving it were also analysed. Teachers' interest in the programme was assessed through two indicators: the overall number of teachers' inscriptions, and their retention rate, which was calculated comparing initial sign-up and real participation figures. Teachers' motivation to participate in the 
programme was specifically addressed in the inscription questionnaire (343 teachers). It was assumed that the kind of motivation mentioned pointed to aspects of the programme that fit teachers' needs. Teachers' satisfaction with the participation in the piloting was explored through the feedback "theme questionnaire" which also contained a question in a 4-point Likert scale and an open question about teachers' satisfaction with the participation. It was assumed that, at a time where teachers were going through a difficult professional period due to the pandemic situation (changes in their teaching habits, necessity of learning new tools for online teaching and of creating new virtual relationships with pupils, etc.), their voluntary participation pointed to the programme fit to their needs. Regarding teachers' suggestion for improving the programme, in addition to the 360 feedback questionnaires about the themes, 950 feedback questionnaires about the lesson plans were received by the end of the e-TAP piloting. The research team analysed all of them $(N=1310)$, looking for programme improvement suggestions. Overall, 195 suggestions were recorded: 46 of them were from preschool teachers and 35 from grades 1 to 3 . NVivo software was used for coding all these aspects.

Ethical considerations. The research received the ethical approval of the Commission of ethics for research with participation of humans of the Department of Education, Psychology and Arts of the University of Latvia on February $4^{\text {th }}, 2021$, approval No. $30-47 / 7$.

\section{Results}

\section{RQ-1. Fit between the e-TAP and the Skola 2030 topics (preschool and grades 1 to 3 )}

To address this question, first the number of Skola 2030 topics/content units that presented a match with e-TAP lesson topics is presented (Table 1), and then the number of e-TAP topics that matched with Skola 2030 topics is described (Table 2).

The results show that a significant number of the Skola 2030 topics matched with e-TAP topics ( $N=116$ out of 261 topics; $44.4 \%$ ), which means that teachers would be able to use e-TAP materials in their subjects. Looking at the number of different topics matched (Table 1, column 2), the average of the 4 areas regarding social sciences and humanities (Cultural understanding, Social and civic education, Languages and Health and sports) was 54\%, while the figure for the 3 other areas (Natural sciences, Mathematics and Technology) was $32 \%$. In pre-school (phase 3), the area with the highest percentage of matches was "Cultural understanding and artistic self-expression": out of the 10 content units included in Skola 2030, seven $(70 \%)$ had at least a match with e-TAP. 
Table 1. School-2030 topics /content units matched with e-TAP topics

\begin{tabular}{|c|c|c|c|}
\hline & $\begin{array}{l}\text { Number of } \\
\text { School-2030 } \\
\text { topics }\end{array}$ & $\begin{array}{l}\text { Number of } \\
\text { different } \\
\text { topics } \\
\text { matched } \\
\end{array}$ & $\begin{array}{l}\text { Total } \\
\text { number of } \\
\text { matches } \\
\text { with e-TAP } \\
\end{array}$ \\
\hline Natural sciences & 22 & 8 & 10 \\
\hline Preschool ( $3^{\text {rd }}$ level) & 8 & 3 & 4 \\
\hline Natural science (grades 1-3) & 14 & 5 & 6 \\
\hline $\begin{array}{l}\text { Cultural understanding and artistic } \\
\text { self-expression }\end{array}$ & 43 & 20 & 51 \\
\hline Preschool ( $3^{\text {rd }}$ level) & 10 & 7 & 32 \\
\hline Music (grades 1-3) & 15 & 3 & 4 \\
\hline Theatre (grades 1-3) & 3 & 3 & 4 \\
\hline Visual arts (grades 1-3) & 15 & 7 & 11 \\
\hline Mathematics & 33 & 8 & 27 \\
\hline Preschool (3 ${ }^{\text {rd }}$ level) & 9 & 4 & 12 \\
\hline Math (grades 1-3) & 24 & 4 & 15 \\
\hline Social and civic education & 25 & 13 & 29 \\
\hline Preschool ( $3^{\text {rd }}$ level) & 13 & 4 & 17 \\
\hline Social sciences (grades 1-3) & 12 & 9 & 12 \\
\hline Technology & 31 & 11 & 20 \\
\hline Preschool (3 $3^{\text {rd }}$ level) & 6 & 2 & 7 \\
\hline Computer science (grades 1-3) & 11 & 4 & 6 \\
\hline Design and technologies (grades 1-3) & 14 & 5 & 7 \\
\hline Languages & 91 & 45 & 73 \\
\hline Preschool ( $3^{\text {rd }}$ level $)$ & 10 & 4 & 15 \\
\hline First foreign language (grades 1-3) & 36 & 15 & 21 \\
\hline Latvian language (grades 1-3) & 18 & 8 & 12 \\
\hline $\begin{array}{l}\text { Minority schools: Latvian language, } \\
\text { literature (grades 1-3) }\end{array}$ & 15 & 12 & 18 \\
\hline $\begin{array}{l}\text { Minority (Russian) language (grades } \\
1-3 \text { ) }\end{array}$ & 12 & 6 & 7 \\
\hline Health and sports & 16 & 11 & 36 \\
\hline Preschool $\left(3^{\text {rd }}\right.$ level $)$ & 7 & 3 & 26 \\
\hline $\begin{array}{l}\text { Sport and health education } \\
\text { (grades 1-3) }\end{array}$ & 9 & 8 & 10 \\
\hline Total & 261 & 116 & 246 \\
\hline
\end{tabular}


On the other hand, the lowest percentage of matches was in the field of "Social and civic education" (31\%: 4 matches out of 13 content units). In grades 1 to 3 , the highest percentage of different topics matched was in the subject "Theatre" (100\%: 3 out of 3 topics matched), and the lowest was in "Mathematics" (17\%: 4 matches out of 24 topics).

Looking at the total number of matches (Table 1, column 3), the data show that, in pre-school, the largest total number of matches were in the thematic areas "Cultural understanding and artistic self-expression" (32 matches) and "Health and sports" (26 matches, which is also the highest number of matches per content unit - almost 9, which indicates that teachers of this subject have a lot of possibilities of using e-TAP programme in their lessons); and the lowest overall number of matches was found in the area of "Natural sciences" ( 4 matches, which is also the lowest number of matches per content unit -0.5 , which indicates a limited number possibilities of using e-TAP programme in these lessons). In grades 1 to 3 , the largest total number of matches were in the subject "Minority schools: Latvian language, literature" (18 matches), and the lowest was in the subject matters "Theatre" and "Music" (4 matches).

The number of lessons of the e-TAP program that matched with the Skola 2030 programme (and therefore could be used when implementing it) was also analysed (Table 2). The overall percent of e-TAP lessons matched was $83 \%$ (49 lessons matched out of 59; see Table 2, columns 1 and 2). Nearly all e-TAP topics in the preschool and in grades 1 and 2 were matched with the Skola 2030 programme, but in grade 3 only 6 out of 11 lessons were matched. The overall number of matches with Skola 2030 (Table 2, column 3) was high: each e-TAP lesson had in average 3.6 matches with Skola 2030 topics or content units.

Table 2. E-TAP lesson plans matched with Skola 2030 topics

\begin{tabular}{|l|l|l|l|}
\hline & $\begin{array}{l}\text { Overall number of } \\
\text { e-TAP lesson plans }\end{array}$ & $\begin{array}{l}\text { Number of different } \\
\text { e-TAP lesson plans } \\
\text { matched }\end{array}$ & $\begin{array}{l}\text { Overall number } \\
\text { of matches with } \\
\text { School-2030 }\end{array}$ \\
\hline Preschool (5 years) & 12 & 12 & 52 \\
\hline Preschool (6 years) & 12 & 11 & 45 \\
\hline Grade 1 & 12 & 10 & 35 \\
\hline Grade 2 & 12 & 10 & 29 \\
\hline Grade 3 & 11 & 6 & 17 \\
\hline Total & $\mathbf{5 9}$ & $\mathbf{4 9}$ & $\mathbf{1 7 8}$ \\
\hline
\end{tabular}




\section{RQ-2. Fit of the e-TAP programme to the Latvian educational context}

The Table 3 presents teachers' rating of e-TAP fit to the different levels of the Latvian socio-ecological system (country, school, teacher, and pupils).

Table 3. Teachers' $(N=169)$ opinion about e-TAP topic fit to contextual needs and values (\%)

\begin{tabular}{|l|c|c|c|c|c|c|c|c|}
\hline & \multicolumn{2}{|c|}{ Yes } & \multicolumn{2}{c|}{ Rather yes } & \multicolumn{2}{c|}{ Rather no } & \multicolumn{2}{c|}{ No } \\
\cline { 2 - 9 } & $n$ & $\%$ & $n$ & $\%$ & $n$ & $\%$ & $n$ & $\%$ \\
\hline $\begin{array}{l}\text { Is the theme topical in } \\
\text { Latvian sociocultural } \\
\text { context? }\end{array}$ & 133 & $79 \%$ & 35 & $21 \%$ & 0 & $0 \%$ & 1 & $1 \%$ \\
\hline $\begin{array}{l}\text { Does the theme fit the } \\
\text { Latvian and international } \\
\text { legislation? }\end{array}$ & 131 & $78 \%$ & 37 & $22 \%$ & 0 & $0 \%$ & 1 & $1 \%$ \\
\hline $\begin{array}{l}\text { Is the theme topical } \\
\text { for your educational } \\
\text { institution? }\end{array}$ & 141 & $83 \%$ & 27 & $16 \%$ & 1 & $1 \%$ & 0 & $0 \%$ \\
\hline $\begin{array}{l}\text { Does the theme fit your } \\
\text { school culture and values? }\end{array}$ & 146 & $86 \%$ & 21 & $12 \%$ & 2 & $1 \%$ & 0 & $0 \%$ \\
\hline $\begin{array}{l}\text { Does the theme fit your } \\
\text { own value system? }\end{array}$ & 153 & $91 \%$ & 15 & $9 \%$ & 1 & $1 \%$ & 0 & $0 \%$ \\
\hline $\begin{array}{l}\text { Does the theme fit } \\
\text { pupils' age, development, } \\
\text { interests? }\end{array}$ & 113 & $67 \%$ & 50 & $30 \%$ & 5 & $3 \%$ & 1 & $1 \%$ \\
\hline
\end{tabular}

The results show that in teachers' opinions, the programme fits very well to the Latvian sociocultural context ( $99 \%$ agree or rather agree). The highest fit regards teachers' value system ( $91 \%$ agree), and the lowest complete agreement regarded the programme fit to pupils' needs and interests (67\%). In their open answers, some teachers suggested some improvements to the programme fit to pupils' development stage, such as considering more carefully at what age it would be convenient to address the topics "harmful substances" and "peer pressure" where some examples about narcotics, alcohol, etc. are presented.

As explained in the methodology section, in addition to these direct indicators, this question also explored teachers' participation and retention level, their motivations and satisfaction for participating in the programme piloting, and their suggestion for improving it.

Teachers' participation and retention level. Overall, 343 teachers signed-up for the programme in January, and 167 of them were teachers working in the grades addressed by this research: 94 of them were 
preschool teachers and 73 worked in grades 1 to 3 . As regards the retention rate, at the end of the piloting, 78 teachers from preschool and 60 from grades $1-3$ had actively participated $(N=138)$. Therefore, the retention rate was $82 \%$, which is very high. Considering the pandemic situation and the voluntary character of participation, these high figures point clearly to the programme fit to teachers' needs and interests.

Teachers' motivation to participate in the programme. In the sign-up questionnaire, answering to the question "What was your motivation to sign-up for the piloting?" 65 occurrences were found mentioning that the themes and materials proposed were attractive. In particular, teachers were motivated by "the materials offered for the piloting, the importance of topics for the full development of children's personality" (respondent No 164 literature and Latvian language teacher), as well as by the fact that "this year pupils in grade 1 are starting to work according to the Skola 2030 curriculum, in which the subject matter "Ethics" is no longer included. So, this project could complement the form time topics perfectly" (respondent No 186 - primary school and math teacher).

Teachers' satisfaction with the participation in the programme. 204 answers were received to the question "Are you satisfied with your participation in the piloting?" $79 \%$ of respondents $(N=161)$ answered "Yes" 20\% $(N=41)$ - "Rather yes" and only $1 \%(N=2)$ - "Rather not". Participants generated comments about the programme value at different places in the data set. 75 mentions to the necessity and timeliness of the materials proposed by the programme were found, which indicates that this aspect of the programme also fit their needs. A respondent (respondent No 132 - social educator), commenting on her satisfaction with the programme and its importance, wrote:

"Thank you for daring to create something like this, it is a good basis for teachers to have a ready-to-use program, where they can also add or adapt part of the lessons. Such a good stepping point! So far, the education guidelines defined the important virtues and values to be highlighted and educated, but how to do it was left to each teacher. This programme is a stepping point with concrete ideas and ready lesson plans".

Teachers' suggestion for improving the programme. 114 teachers' suggestions for improving the programme in preschool and grades 1 to 3 were recorded. The main suggestions regarded the necessity of more time for each lesson and the convenience of elaborating some new materials (16 times each), to have a more active learning process (15 times), to simplify the language used (14 times) and to improve the visual presentation of the slides (12 times). There were also some references to the topic fit to the pupils' age, the video materials, and the logic succession of the lessons. 


\section{Discussion}

The findings of this study show that the e-TAP programme had a good thematic fit with Skola 2030 programme. In this context, an interesting point is that the field of the Natural science had one of the lowest numbers of thematic matches with the virtue education programme, which would make difficult to teachers of these subjects to use the materials provided by e-TAP in their teaching hours. The question arises whether it is possible at all to implement moral education across the curriculum in science subjects. Recent research has established that science learning can foster pupils' virtues such as credibility, responsibility, respect, care, citizenship, courage, aspiration and honesty (Rubini et al., 2018), because in science learning students are trained to describe the phenomena rigorously, to use the right research techniques, and to draw conclusions on the basis of evidence, which enable them to take reasonable, public-interest-sensitive, environmentally friendly and sustainable decisions (Logins et al., 2020). The materials provided by the project "Teaching Character Through Subjects" of the Jubilee Centre for Character and Virtues support this claim (see https:// www.jubileecentre.ac.uk/1676/character-education/teacher-resources/ teaching-character-through-subjects).

The results of this research also show the high fit of the e-TAP programme to the sociocultural context of Latvia. This result could seem surprising, given that the original programme was created in a different cultural setting (the UK). Recent research has addressed the transfer of educational interventions in new cultural settings (Leberman, \& McDonald, 2016). The transfer of the e-TAP programme, done by qualified specialists in the field and through a rigorous research process, complies with the conditions of a successful cultural transfer as stated by Marsiglia \& Booth (2015): "understanding of the deep theoretical structure of the original intervention, and rigorous evaluation" (p. 429).

Teachers play an important role in pupils' socio-emotional and moral education, and they need support for this task. Society expects educators to be moral exemplars of virtues and values through their professional work (Lumpkin, 2008). However, recent research argues that teachers often lack materials and knowledge to successfully implement moral education in practice (Schonert \& Kimberly, 2017). This thesis is confirmed by the findings of this study: despite the fact that traditional values are solidly embedded in the Latvian mentality, teachers' answers point to the need for support in this field and suggest that the e-TAP programme could be the key to a high-quality transfer of moral values and virtues to children, since the lesson plans developed are not only useful for the educator, but also a tool to strengthen existing knowledge and beliefs so that they can be passed on to pupils. 
How is the e-TAP program related to Latvian traditions? This relationship is mainly confirmed by the fact that $91 \%$ of teachers $(N=153)$ claimed that they completely agree that this programme is consistent with their own value system (See Table 3, row 5). The e-TAP lesson plans at preschool and grades 1 to 3 also highlight virtues that permeate Latvian traditions and folk songs, such as kindness, honesty, dignity, courage, pleasure, care, love, love of work, etc. (Siliņa-Jasjukeviča et al., 2008). Updating these virtues at an early age would promote children's understanding of universal human values, Latvian lifestyle, cultural heritage, traditions, and their conservation (Latvijas Vēstnesis, 2016, 141). This programme therefore directly relates to the renewing and enlivenment of Latvian traditions, the understanding and interiorization of Latvian values, and the development of the Latvian cultural space today.

One of the limits of this study is the focus on preschool and grade 1 to 3 . More research is necessary for testing the programme fit at higher levels of education. For future research, the programme fit to the upbringing themes proposed by the National Centre of Education of the Republic of Latvia (NCE, 2016) could be explored. In addition, the focus on the thematic fit should be enlarged also to other pedagogical aspect, in particular the didactic methods to use in online environment. Finally, the teachers' views presented in the study should be completed with those of parents and even children themselves for enhancing reliability.

\section{Conclusions}

The main conclusions of this research are the following ones:

- The virtue education programme e-TAP has a good thematic fit with Skola 2030 programme: $44.4 \%$ of the Skola 2030 curriculum topics match with the topics of e-TAP.

- The social sciences and humanities areas has the highest number of matches with e-TAP, but the area of Natural sciences had the lowest number. It would be convenient to improve the e-TAP programme in this field.

- Mostly all of e-TAP lesson plans (83\%) could be used when implementing the current Skola 2030 curriculum.

- Teachers participating in the research massively support the thesis that the e-TAP programme fits the Latvian educational context. They agree $(91 \%)$ or rather agree $(9 \%)$ that the programme correspond to their needs, expectations, and values.

- The high fit of the programme to the Latvian sociocultural context is also supported by teachers' high interest in participating in its piloting, and their satisfaction with the piloting process. 
- According to the teachers' comments about the programme topics and materials, the e-TAP programme is a serious support for teachers to implement the moral education of pupils as foreseen in the Law of Education of the Republic of Latvia.

- The e-TAP programme can be considered as an innovation in the Latvian education system. It is a novel support for educators that is directly related to Latvian traditions and enhances the understanding and preservation of Latvian values and the development of the Latvian cultural space nowadays.

The e-TAP programme, with the ongoing improvements, is a serious research-based support to teachers in implementing moral education at school in Latvia. It highlights the relevance of traditions for virtue education and how they can be successfully combined with pedagogical innovations, while complying with the national guidelines of moral education.

\section{References}

Alewov, U. \& Utemuratova, Y. M. (2021). The unity of education, culture and mentality as the basis for the transformation of students' values, taking into account national and regional traditions. European Scholar Journal, 2(4), 14-16. Retrieved from: https:// www.scholarzest.com

Baldunčiks, J. \& Pokrotniece, K. (1999). Tradīcija. No Svešvārdu vārdnīca. Apgāds Jumava.

Bumbarger, B. K. (2020). Program fit, feasibility, and effectiveness study. Evidence-based Prevention and Intervention Support Center (EPISCenter), Prevention Research Center, Penn State University. Retrieved from: http://www.episcenter.psu.edu/sites/default/ files/2020-07/Module-Four-Worksheet_Program-Fit-Feasibility-and-Effective-Study_0.docx

CMFR - Clearinghouse for Military Family Readiness (2020). A tool for assessing program fit and feasibility. Pennsylvania State University: Clearinghouse for military family readiness. Retrieved from: https://blueprintsconference.org/presentations/T5-B_Program_Fit_ and_Feasibility_Tool.pdf

Eldridge, S. M., Lancaster, G. A., Campbell, M. J., Thabane, L., Hopewell, S., Coleman, C. L., \& Bond, C. M. (2016). Defining feasibility and pilot studies in preparation for randomised controlled trials: Development of a conceptual framework. PLOS One, 11(3), 1-22. https:// doi.org/10.1371/journal.pone.0150205

Fernández González, M. J. (2019). The moral education of pupils in Latvian schools [Skolēnu morālā audzināšana Latvijas skolās]. Popular science report. Riga: Latvijas Universitātes Pedagoǵijas zinātniskais institūts. Retrieved from: https://dspace.lu.lv/ dspace/handle/7/46498

Fernández González, M. J., Elksne, G., \& Sidorova, A. (2021). e-TAP curriculum for virtue education: A fit analysis to the Skola 2030 curriculum. Proceedings of the International Scientific Conference "Society. Integration. Education" Volume II, May $28^{\text {th }}-$ $29^{\text {th }}, 2021$ (pp. 214-223). Rezekne, Latvia: Rezekne Academy of Technologies. https:// doi.org/10.17770/sie2021vol2.6171

Ferreiro, M. D. F., Sheikh, F. A., Reidolf, M., de Sousa, C., \& Bhaduri, S. (2019). Tradition and innovation: Between dynamics and tensions. African Journal of Science, 
Technology, Innovation and Development, 11(5), 533-542. https://doi.org/10.1080/2042 1338.2018.1558743

Hong, S., Oxley, L., \& McCann, P. (2012). A survey of the innovation surveys. Journal of Economic Surveys, 26(3), 420-444.

Izglītỉbas likums [Education Law] (17.11.1998), Latvijas Vēstnesis, 224, 19.11.2020. Retrieved from: https://www.vestnesis.lv/ta/id/50759-izglitibas-likums

Izglītojamo audzināšanas vadlīnijas un informācijas, mācību līdzekḷu, materiālu un mācību un audzināšanas metožu izvērtēšanas kārtība [Guidelines for pupils' moral education and procedures for assessment of the information, learning tools, materials, and methods for moral education]. Latvijas Vēstnesis, 25.07.2016, 141. Retrieved from: https://www.vestnesis.lv/op/2016/141.4

Katila, R. (2002). New product search over time: past ideas in their prime? Academy of Management Journal, 45(5), 995-1010.

Kiope, M. (2015). Tikumiskā audzināšana ir cilvēka morālā spēka attīstīšana [Virtue education is the development of the person's moral strength]. Retrieved from: http:// asociacijagimene.lv/asoc-prof-m-kiope-tikumiska-audzinasana-ircilveka-morala-spekaattistisana/

Kūle, M. (2005). Tradīcijas kā kultūras vērtību nesējas [Traditions as bearers of cultural values]. Latvijas Vēstnesis, 26.07.2005., Nr. 116. Retrieved from: https://www.vestnesis. $\mathrm{lv} / \mathrm{ta} / \mathrm{id} / 113217$

Lakota, A. B., Širca, N. T., \& Dermol, V. (2016). Virtues - the centre of quality education system - for successful integration in the international society. Procedia - Social and Behavioral Sciences, 221, 302-307. https://doi.org/10.1016/j.sbspro.2016.05.119

Leberman, S., \& McDonald, L. (2016). The transfer of learning: Participants' perspectives of adult education and training. CRC Press.

Logins, J., Birziņa, R., Dudareva, I., \& Kalvāne, G. (2020). Dabaszinātñu mācību metodika [Teaching methodical materials for Natural sciences]. Riga: LU Akadēmiskais apgāds.

Lumpkin, A. (2008). Teachers as role models teaching character and moral virtues. Journal of Physical Education, Recreation \& Dance, 79(2), 45-50.

Marsiglia, F. F., \& Booth, J. M. (2015). Cultural adaptation of interventions in real practice settings. Research on Social Work Practice, 25(4), 423-432. https://doi. org/10.1177/1049731514535989

Mitchell, C. J. (2013). Creative destruction or creative enhancement? Understanding the transformation of rural spaces. Journal of Rural Studies, 32, 375-387.

NCE - National Centre of Education of the Republic of Latvia. (2016). Recommendations for the form time programme implementation [Ieteikumi Klases stundu programmas istenošanai Metodiskie ieteikumi]. Retrieved from: https://registri.visc.gov.lv/audzinasana/dokumenti/metmat/ieteikumi_klases_st_progr_ist.pdf

Pīgozne, T., Surikova, S., \& Fernández González, M. J. (2020). Adaptation of a teacher training programme for character education to Latvian context. In: L. Daniela (ed.), Human, technologies and quality of education - 2020. Proceedings of scientific papers (pp. 7-18). Riga: Latvijas Universitāte. https://doi.org/10.22364/htqe.2020.01

Rubini, B., Permanasari, A., \& Permana, I. (2018). Building character through science learning with scientific literacy based. IOP Conference Series: Materials Science and Engineering, 288, 012030. https://doi.org/10.1088/1757-899x/288/1/012030 
Schonert, R., Kimberly A. (2017). Social and emotional learning and teachers. Future of Children, 27(1), 137-155.

Serdyukov, P. (2017). Innovation in education: what works, what doesn't, and what to do about it? Journal of Research in Innovative Teaching \& Learning, 10(1), 4-33. doi:10.1108/jrit-10-2016-0007

Siliņa-Jasjukeviča, G., Oḷenkins, S., Kārkle, A., Mennika, B., Žogota, I., Matēviča, G., \& Kḷaviña, I. (2008). Tradicionālā kultūra bērniem [Traditional culture for children]. Riga: Raka.

Skola 2030. (2017). Education for modern competence: Description of study content and approach [Izglìtība mūsdienīgai lietpratībai: mācību satura un pieejas apraksts]. Nacional Centre for Education. Retrieved from: https://static.lsm.lv/documents/ge.pdf

Skola 2030. (2020). No 1. septembra pakāpeniski 1., 4., 7. un 10. klasēs sāk ieviest jauno mācïbu saturu un pieeju. Retrieved from: https://www.skola2030.lv/lv/jaunumi/zinas/ no-1-septembra-pakapeniski-1-4-7-un-10-klases-sak-ieviest-jauno-macibu-saturu-unpieeju

The Jubilee Centre for Character and Virtues. (2017). A Framework for Character Education in Schools. Birmingham: University of Birmingham. Retrieved from: https://www. jubileecentre.ac.uk/527/character-education/framework 